\title{
DETERMINANTY ZADOWOLENIA Z ŻYCIA POLAKÓW Z POKOLENIA X
}

\section{WSTĘP}

Zadowolenie z życia, którego synonimem jest często pojęcie szczęścia, jest głównym, ale nie zawsze świadomym, celem ludzkich działań i pragnień. W dążeniu do szczęścia dla każdego z nas ważny jest nie tylko jego poziom (jestem mało, średnio bądź bardzo szczęśliwy), lecz także źródło tego szczęścia, w takim sensie, czy jesteśmy zadowoleni z tych dziedzin życia, na których rzeczywiście nam zależy. Nie jest bowiem tym samym szczęściem bycie maksymalnie zadowolonym ze sfery życia, która nie jest dla nas aż tak bardzo ważna, jak pełne zadowolenie z dziedziny najistotniejszej w naszym systemie wartości.

W badaniach nad szczęściem dominują dwa ujęcia: „dół-góra” oraz „góradół”. To pierwsze zakłada, że im lepiej jest nam „na dole”, to znaczy w poszczególnych dziedzinach życia, tym lepiej jest też „na górze” - w całym naszym życiu. W tej koncepcji poczucie szczęścia jest wynikiem matematycznego rachunku na zbiorze satysfakcji cząstkowych z uwzględnieniem wszystkich ważnych aspektów życia. Według takiego rachunku ogólne zadowolenie z życia jest sumą (ewentualnie jakoś ważona) zadowolenia z partnera, dzieci, pracy, pieniędzy, miejsca zamieszkania, zdrowia i wielu, wielu innych sfer życia. Im więcej zarabiamy, im więcej posiadamy, a zatem im lepsza jest nasza sytuacja materialna, tym bardziej jesteśmy z niej zadowoleni i w konsekwencji tym bardziej ogólnie jesteśmy szczęśliwi. Z kolei im lepsze są nasze relacje z innymi ludźmi, im mniej się kłócimy ze współmałżonkiem, im mniej problemów przynoszą nam dzieci, tym jesteśmy bardziej pogodni i zadowoleni z życia (społecznego oraz całościowo).

W rozważaniach nad szczęściem rozróżnia się także dwa nurty teoretyczne: hedonistyczny i eudajmonistyczny. W ilościowych badaniach empirycznych, czy to opartych na eksperymentach, czy wykorzystujacych statystyczna analizę danych z badań ankietowych, najczęściej stosowany jest ten pierwszy, według którego nie liczy się, jakie ważne społecznie cele człowiek realizuje (np. poświęca się dla dobra innych), ale czy jest zadowolony ze swojego życia i czy życie to daje mu więcej radości czy więcej bólu.

Uwzględnienie obu tych perspektyw (ujęcia „dół-góra” oraz nurtu hedonistycznego) pozwala uzyskać subiektywny i całościowy wskaźnik zadowolenia z życia, który uwzględnia satysfakcje cząstkowe (z poszczególnych dzie- 
dzin) oraz ich ważność w systemie wartości człowieka. Dzięki tak policzonemu wskaźnikowi zadowolenia możliwe było wyznaczenie celu niniejszych rozważań: weryfikacja, czy istnieją czynniki (cechy respondentów), które wpływaja na zróżnicowanie ogólnego zadowolenia z życia (a jeśli tak, to w jakim kierunku i w jakim stopniu), a grupa, kórą wybrano do badania, to Polacy w wieku 35 lat i więcej, czyli osoby reprezentujące tzw. pokolenie X (tzn. osoby urodzone w drugiej połowie XX w.). Pokolenie X przez socjologów opisywane jest jako społeczeństwo zagubione w chaosie współczesności, szukające odpowiedzi na trudne pytania, sensu własnej egzystencji, ale dzięki temu bardziej refleksyjne, co z perspektywy poruszanego tematu (i rzetelności uzyskiwanych wyników) jest wielce pożądane.

\section{METODOLOGIA BADANIA}

Do zrealizowania tak sformułowanego celu wykorzystano dane z przeprowadzonego samodzielnie w pierwszym półroczu 2017 r. badania ankietowego ${ }^{1}$. Objęło ono próbę 1110 respondentów z województwa wielkopolskiego, reprezentantów pokolenia X.

Jedną z kwestii poruszanych w tym badaniu było pytanie respondentów o ich poziom zadowolenia z 21 dziedzin (sfer) życia ${ }^{2}$ oraz o to, jak ważne sa dla nich te dziedziny. Odpowiedzi, jakich mogli udzielać ankietowani co do ważności tych sfer, polegały na zaznaczeniu jednego z 5 wariantów: 1 - „w ogóle mi nie zależy” (na danej sferze życia), 2-,raczej mi nie zależy”, 3 - „,ani mi zależy/ ani nie zależy”, 4 - „raczej mi zależy”, 5 - „bardzo mi zależy” (na tej dziedzinie życia); z kolei zadowolenie z badanych dziedzin respondenci również wyrażali na skali 5-punktowej, gdzie: 1 - „jestem bardzo niezadowolony”, 2 - ,jestem raczej niezadowolony, 3 -,jestem ani zadowolony, ani niezadowolony”, 4 -,jestem raczej zadowolony”, 5 - ,jestem bardzo zadowolony”.

Przed przystapieniem do policzenia ogólnego wskaźnika zadowolenia odpowiedzi te zostały najpierw przekształcone tak, aby ważność poszczególnych dziedzin życia traktować jako zmienną przedziałowa, przyjmująca wartości od 0 (,w ogóle mi nie zależy”) do 1 („,bardzo mi zależy”), zadowolenie zaś wyrażało się na skali od -1 (maksymalne niezadowolenie) do +1 (maksymalne zadowolenie). Celem tych transformacji było uzyskanie wskaźników łatwiejszych w interpretacji. Następnie w wyniku połączenia tych aspektów powstał specjalny ważony wskaźnik zadowolenia łącznie ze wszystkich sfer, a jego konstrukcja była następująca:

1 Badanie finansowane ze środków NCN w ramach projektu pt. „Uwarunkowania i konsekwencje decyzji życiowych ludności na przykładzie Wielkopolski” (UMO-2013/11/D/H54/03933).

2 Były to następujące sfery (widoczne także na wykresie 2): życie prywatne, życie jako rodzic, życie rodzinne, życie towarzyskie, wykształcenie, wiedza i umiejętności, osiąnnięcia i sukcesy, praca, aktywność społeczna, sytuacja finansowa, stan posiadania, warunki mieszkaniowe, niezależność, bezpieczeństwo, sprawność, zdrowie, wygląd, życie seksualne, życie religijne, czas wolny, prestiż. 


$$
Z_{\text {ogóne }}=\frac{\sum_{i=1}^{21} W_{i} \cdot Z_{i}}{21},
$$

gdzie $Z_{\text {ogólne }}$ jest ogólnym, ważonym wskaźnikiem zadowolenia ze wszystkich 21 dziedzin życia, $W_{i}$ - waga przyznawaną danej sferze, a $Z_{i}-$ „,czystym” (nieważonym) zadowoleniem z tej dziedziny.

Ważony wskaźnik zadowolenia z życia, podobnie jak „,czyste” (nieważone) wskaźniki czasstkowe, przyjmuje wartości od -1 do 1 ( $Z>0$ oznacza odczuwane zadowolenie, $Z<0$ niezadowolenie, im bliżej 1 , tym respondent jest szczęśliwszy, a im bliżej -1, tym bardziej nieszczęśliwy), ale uwzględnia on wszystkie 21 sfer życia wraz z ich ważnością w systemie wartości respondentów. Należy ponadto wyjaśnić, że zadowolenie równe 0 respondent mógł uzyskać, gdyby często (dla wielu dziedzin) wskazywał, że ,ani jest zadowolony, ani niezadowolony" z danej sfery lub gdyby był zadowolony z danej sfery życia, ale wiele takich dziedzin nie odgrywało w jego życiu w ogóle żadnej roli (w ogóle mu na nich nie zależało), co dla ogólnego dobrostanu człowieka też nie jest sytuacja pożądaną, świadczy bowiem o pewnym wycofaniu z niektórych sfer, braku zaangażowania. Może się oczywiście zdarzyć tak, że z niektórych sfer respondent jest zadowolony $\left(Z_{i}>0\right)$, z niektórych nie $\left(Z_{i}<0\right)$, co spowoduje, że łączny wskaźnik zadowolenia $(Z)$ też będzie oscylował wokół 0. Należy też dodać, że w przyjętej metodologii ocena łącznego zadowolenia wynosząca +1 (maksymalne ważone zadowolenie) jest bardzo trudna do uzyskania, ponieważ aby ją otrzymać - trzeba być maksymalnie zadowolonym ze wszystkich uwzględnionych w badaniu sfer życia oraz te sfery muszą w naszym życiu odgrywać bardzo ważną rolę. Innymi słowy: będziemy maksymalnie szczęśliwi, gdy nie wycofamy się z żadnych ważnych dziedzin naszego życia oraz gdy bardzo się z nich cieszymy.

Oprócz wyznaczenia wskaźników zadowolenia z życia dla każdego respondenta osobno, na następnym etapie analizy postanowiono sprawdzić, jak oceny te koreluja z wybranymi cechami ankietowanych. Cechy te dobierano tak, aby opisywały warunki życia dla każdej z uwzględnionych w badaniu 21 dziedzin życia. Przykładowo dla dziedziny „warunki mieszkaniowe” były to: wielkość miejscowości zamieszkania, powierzchnia mieszkalna, liczba osób, które na co dzień tam mieszkaja, oraz to, kto jest właścicielem domu/ mieszkania. Sam wybór zmiennych, które tworzą tzw. obiektywne warunki życia i od których zależeć może dobrostan człowieka, nie był jednak sprawa prosta. Przegląd badań z tego zakresu ${ }^{3}$ pokazuje jednak, że lista potencjalnych czynników wykorzystywanych w badaniach nad szczęściem jest bardzo długa, począwszy od cech demograficznych (płci, wieku), przez społeczne (stan cywilny, wykształcenie), ekonomiczne (posiadania pracy, sytuacja finansowa), a skończywszy na zdrowotnych (m.in. sprawność) oraz tych związanych z psy-

${ }^{3}$ Np. Khan (2015); Boarini (2015); Christoph (2003); Ostasiewicz (2004); czy jedno z pionierskich studiów: Campbell (1976). 
chika człowieka (poziom niezależności, bezpieczeństwa) i cechami osobowości. W toku długiej tradycji badań nad szczęściem wypracowano jednak już pewne standardy metodologiczne. Pierwotnie lista czynników - determinant szczęścia - sięgała niekiedy nawet kilkuset zmiennych, ale autorzy takich opracowań, wspomagając się metodami statystycznymi, udowodnili, że lista ta nie musi być tak obszerna i że na szczęście w największym stopniu oddziałuje kilkanaście głównych czynników (które konkretnie, to zależy jeszcze od metodyki badania, czasu i zakresu przestrzennego). Przy projektowaniu własnych badań ankietowych starano się, aby możliwie najszerzej opisywały one sytuację życiowa respondentów, oprócz standardowych cech (płeć, wiek itp.), starano się też dodać kilka nowych czynników (np. jakie sukcesy odnieśli i jakie porażki ponieśli w swoim życiu respondenci). Wszystkie uwzględnione $\mathrm{w}$ badaniu cechy prezentuje tabela 1 .

\section{Tabela 1}

Czynniki determinujące poziom zadowolenia uwzględnione w podjętym badaniu

\begin{tabular}{|c|c|}
\hline $\begin{array}{l}\text { Cechy związane } \\
\text { z relacjami z innymi } \\
\text { ludźmi }\end{array}$ & $\begin{array}{l}\text { 1) Stan cywilny (zm. jakościowa, nominalna, } 5 \text { wariantów) } \\
\text { 2) Posiadanie dzieci (zm. jakościowa, } 2 \text { warianty: T/N) } \\
\text { 3) Liczba dzieci (zm. ilościowa) } \\
\text { 4) Prestiż społeczny, szacunek otoczenia (zm. jakościowa, } \\
\text { porządkowa) }\end{array}$ \\
\hline $\begin{array}{l}\text { Cechy związane } \\
\text { z edukacją, karierą }\end{array}$ & $\begin{array}{l}\text { 5) Poziom wykształcenia (zm. jakościowa, } 4 \text { warianty) } \\
\text { 6) Posiadanie specjalistycznej wiedzy (zm. jakościowa, } \\
2 \text { warianty: T/N) } \\
\text { 7) Posiadanie wyjątkowych umiejętności (zm. jakościowa, } \\
2 \text { warianty: T/N) } \\
\text { 8) Osiagnięcie nieprzeciętnych sukcesów (zm. jakościowa, } \\
2 \text { warianty: T/N) } \\
\text { 9) Doświadczenie dotkliwych porażek (zm. jakościowa, } \\
2 \text { warianty: T/N) } \\
\text { 10) Posiadanie pracy (zm. jakościowa, } 2 \text { warianty: T/N) } \\
\text { 11) Status emeryta (zm. jakościowa, } 2 \text { warianty: T/N) } \\
\text { 12) Aktywne udzielanie się społecznie (zm. jakościowa, } \\
2 \text { warianty: T/N) }\end{array}$ \\
\hline $\begin{array}{l}\text { Cechy związane } \\
\text { z sytuacją majątkową }\end{array}$ & $\begin{array}{l}\text { 13) Miesięczne dochody netto (zm. quasi-ilościowa) } \\
\text { 14) Poziom oszczędności (zm. quasi-ilościowa) } \\
\text { 15) Poziom zadłużenia (zm. quasi-ilościowa) } \\
\text { 16) Posiadany majątek (zm. quasi-ilościowa) } \\
\text { 17) Miejsce zamieszkania (zm. jakościowa, } 5 \text { wariantów) } \\
\text { 18) Posiadanie na własność lokalu mieszk. (zm. jakościowa, } \\
2 \text { warianty: T/N) } \\
\text { 19) Liczba domowników (zm. ilościowa) } \\
\text { 20) Powierzchnia mieszkania na } 1 \text { os. (zm. ilościowa) } \\
\text { 21) Bycie niezależnym finansowo (zm. jakościowa, } 2 \text { warianty: } \\
\text { T/N) }\end{array}$ \\
\hline
\end{tabular}




\begin{tabular}{|l|l|}
\hline $\begin{array}{l}\text { Cechy związane } \\
\text { ze zdrowiem } \\
\text { (i pokrewne) }\end{array}$ & $\begin{array}{l}\text { 22) Poziom wolności, swobody (zm. jakościowa, porządkowa) } \\
\text { 23) Poziom sprawności i stan zdrowia (zm. jakościowe, } \\
\text { porządkowe) }\end{array}$ \\
24) Niepełnosprawność (zm. jakościowa, 2 warianty: sprawny/ \\
niepełnosprawny) \\
25) Wskaźnik BMI (zm. ilościowa) \\
26) Atrakcyjność fizyczna (zm. jakościowa, porządkowa) \\
27) Liczba kontaktów seksualnych na miesiąc (zm. ilościowa) \\
28) Stosunek do wiary (zm. jakościowa, 2 warianty: wierzy/ nie \\
wierzy) \\
29) Ilość czasu wolnego na dzień (zm. ilościowa)
\end{tabular}

Zmienna quasi-ilościowa oznacza w tym przypadku, że wartości liczbowe ją reprezentujące zostały oszacowane na podstawie środków przedziałów

Źródło: opracowanie własne.

Po opracowaniu listy 41 czynników (potencjalnych determinant zadowolenia z życia) w kolejnym kroku należało ustalić, które z nich mają znaczenie, a które nie, dla odczuwanego przez respondentów z Wielkopolski poziomu szczęścia oraz jaki jest kierunek i siła tego wpływu. Z uwagi na wielowymiarowość oddziaływania badanych czynników na wskaźnik zadowolenia z życia zastosowano analizę regresji wielorakiej, w wyniku której został skonstruowany model opisujący wpływ tych czynników na całościowy poziom zadowolenia, wraz z informacją o istotności danego czynnika oraz jakości całego modelu (tabela 2).

\section{REZULTATY BADAWCZE}

Przed przystapieniem do konstrukcji modelu przygotowano histogram ogólnego wskaźnika zadowolenia z życia, aby sprawdzić, jaki rozkład przyjmuje, i czy możliwe będzie stosowanie klasycznej procedury analizy regresji, 
która najlepiej sprawdza się w sytuacji, gdy rozkład zmiennej zależnej jest zbliżony do rozkładu normalnego. Jak pokazuje wykres 1 , badana zmienna cechuje się dość symetrycznym rozkładem (współczynnik skośności wyniósł w tym przypadku -0,44, kurtoza: -0,28), aczkolwiek test Shapiro-Wilka na normalność rozkładu każe odrzucić (na poziomie $\alpha=0,05$ ) hipotezę o normalności rozkładu ogólnego zadowolenia. Co ciekawe, tylko 25 respondentów $(2,3 \%)$ jest niezadowolonych ze swojego całego życia (wskaźnik $Z$ mniejszy od 0).

\section{Wykres 1}

Rozkład ważonego, ogólnego zadowolenia z życia wśród badanych respondentów

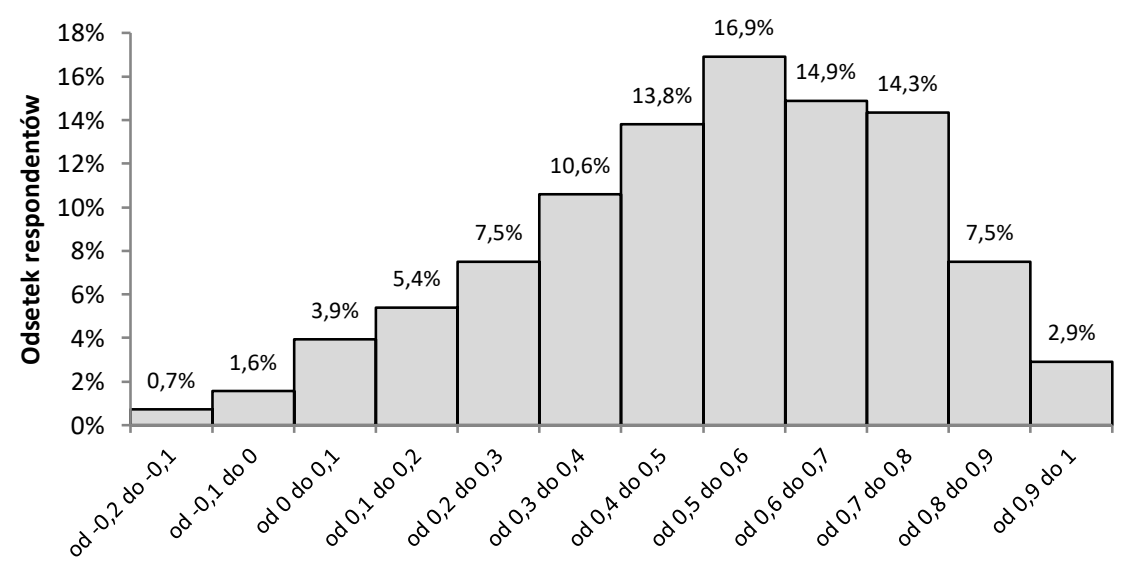

Źródło: opracowanie własne na podstawie danych ankietowych.

Wykres 2 prezentuje z kolei, które wskaźniki cząstkowe (zadowolenie z poszczególnych sfer życia) składają się na ogólny wskaźnik zadowolenia, jakie było średnie zadowolenie $\mathrm{z}$ tych dziedzin $\mathrm{w}$ badanej grupie 1110 respondentów oraz jaką średnią ważność przypisywali oni tym dziedzinom (stosowany w opracowaniu wskaźnik zadowolenia z życia uwzględnia bowiem oba te aspekty). Okazało się, że ankietowani najbardziej byli zadowoleni ze swojej niezależności, z warunków mieszkaniowych, z życia prywatnego (z partnerem) oraz z życia jako rodzic, najmniej zaś - z aktywności społecznej, sytuacji finansowej oraz życia seksualnego. Z kolei dziedzinami, na które zwracali największą uwagę, były: zdrowie, sprawność i bezpieczeństwo, natomiast najmniej zależało im na aktywności społecznej, prestiżu i życiu religijnym.

W dalszej części analizy skonstruowano model regresji liniowej, w którym zmienna zależną był ważony wskaźnik zadowolenia z życia, a zmiennymi niezależnymi - wszystkie wymienione w części metodologicznej (tabela 1) cechy. Przed przystapieniem do obliczeń w przypadku niektórych czynników dokonano połączenia pewnych kategorii w ramach danej cechy, tak aby otrzymać zmienne dychotomiczne, zero-jedynkowe: uczyniono tak na przykład w przypadku wykształcenia, łącząc w jedną kategorię wszystkie osoby, które nie ukończyły studiów. 


\section{Wykres 2}

Średnia ważność oraz zadowolenie z poszczególnych sfer życia według opinii respondentów

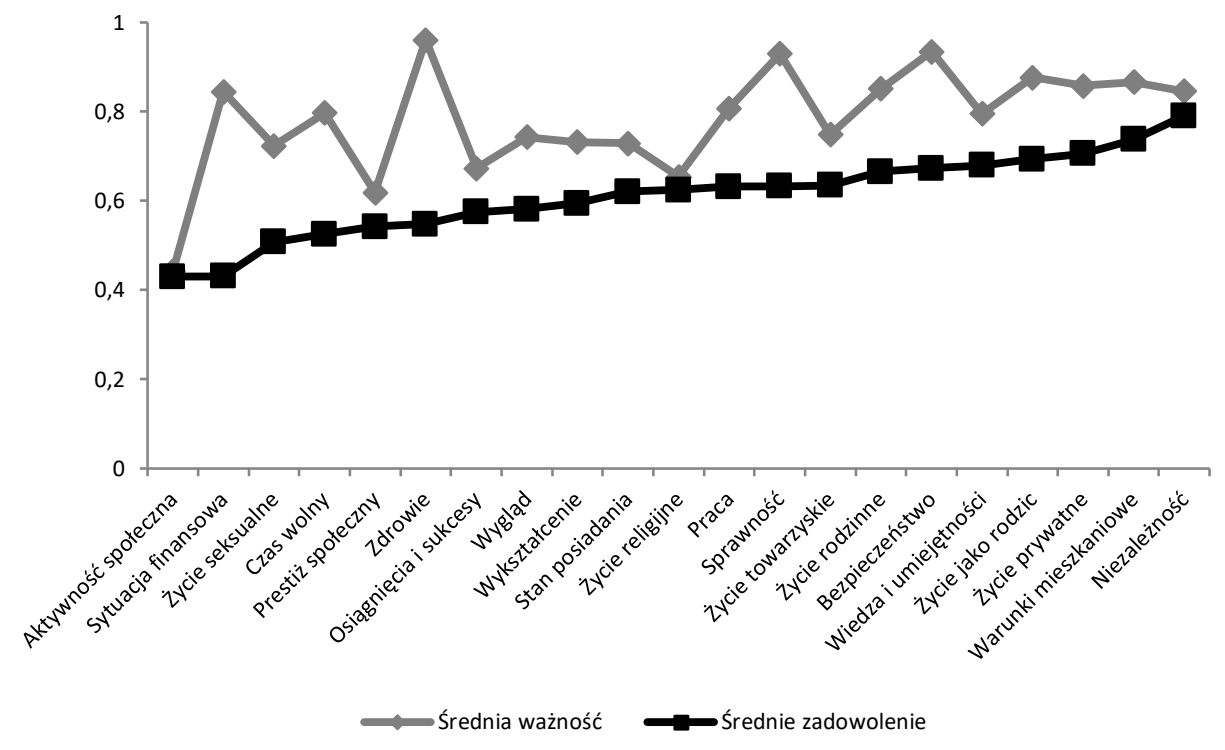

Źródło: opracowanie własne.

Tabela 2 prezentuje oszacowane parametry modelu, ich błędy szacunkowe, testy $t$ na istotność danej zmiennej znajdujacej się $\mathrm{w}$ modelu oraz poziom $p$-value. Na podstawie otrzymanych wyników można sprawdzić, które czynniki istotnie (na przyjętym poziomie istotności 0,05) i w jaki sposób (kierunek oddziaływania) wpływają na ważone, ogólne zadowolenie z życia. Do takich czynników wśród cech jakościowych należą: posiadanie dzieci (kto je ma, ten jest przeciętnie bardziej zadowolony z życia, średnio o 0,064 pkt na skali od -1 do +1 ); bycie niezależnym finansowo (podnosi poziom szczęścia średnio o 0,045 pkt), mieszkanie w Poznaniu (obniża odczuwanie szczęścia średnio o 0,048 pkt); oraz doświadczenie w życiu jakiejś wyjątkowo bolesnej porażki (obniża odczuwane szczęście przeciętnie o 0,129 pkt). Z kolei wśród cech ilościowych na zadowolenie z życia wpływaja: liczba dzieci (wśród osób je posiadających): kto ma ich więcej, ten jest mniej zadowolony z życia (każde kolejne dziecko średnio odbiera 0,018 pkt zadowolenia); wartość majątku (z każdym tysiącem złotych majątku zadowolenie respondentów rośnie średnio o 0,104 pkt); poziom wolności i swobody, poziom bezpieczeństwa i poziom sprawności (wzrost każdej z tych cech pociaga za sobą wzrost zadowolenia); stan zdrowia (im lepszy, tym respondenci sa bardziej szczęśliwi); liczba kontaktów seksualnych w miesiącu (zwiększa poziom szczęścia); poziom prestiżu (podnosi zadowolenie z życia); z kolei z cech psychologicznych: poziom ekstrawersji (towarzyskości) oraz sumienności zwiększaja poziom zadowolenia. Wszystkie te czynniki okazały się statystycznie istotnie (na poziomie istotności co najwyżej 0,05) wpływać na ogólne zadowolenie z życia. Należy jednak dodać, że jakość dopasowania modelu (mierzona współczynnikiem 
determinacji $R$-kwadrat) jest średnio zadowalająca, co świadczy o tym, że jest jeszcze wiele innych potencjalnych czynników (poza tymi, które uwzględniono w badaniu) mogacych lepiej wyjaśnić to, od czego zależy zadowolenie z życia Polaków reprezentujących pokolenie X.

\section{Tabela 2}

Model regresji opisujący poziom ważonego, ogólnego zadowolenia z życia wśród badanych respondentów

\begin{tabular}{|c|c|c|c|c|}
\hline Zmienna niezależna & $\begin{array}{c}\text { Oszacowanie } \\
\text { parametru }\end{array}$ & $\begin{array}{c}\text { Błąd } \\
\text { standardowy }\end{array}$ & Test $t$ & $p$-value \\
\hline (Wyraz wolny) & $-0,471$ & 0,071 & $-6,656$ & 0,0000 \\
\hline $\begin{array}{l}\text { Posiadanie dzieci } \\
(0=\text { nie, } 1=\text { tak })\end{array}$ & 0,064 & 0,026 & 2,506 & 0,0125 \\
\hline Liczba dzieci & $-0,018$ & 0,008 & $-2,413$ & 0,0161 \\
\hline $\begin{array}{l}\text { Bycie niezależnym } \\
\text { finansowo }(0=\text { nie, } 1=t a k)\end{array}$ & 0,045 & 0,018 & 2,505 & 0,0125 \\
\hline Wartość majątku* & 0,104 & 0,031 & 3,354 & 0,0008 \\
\hline $\begin{array}{l}\text { Mieszka w Poznaniu } \\
(0=\text { nie, } 1=t a k)\end{array}$ & $-0,048$ & 0,020 & $-2,453$ & 0,0145 \\
\hline $\begin{array}{l}\text { Doznanie wielkiej porażki } \\
\text { życiowej } \\
(0=\text { nie, } 1=t a k)\end{array}$ & $-0,129$ & 0,031 & $-4,124$ & 0,0000 \\
\hline Poziom wolności, swobody & 0,044 & 0,011 & 4,096 & 0,0000 \\
\hline Poziom bezpieczeństwa & 0,045 & 0,009 & 5,064 & 0,0000 \\
\hline Poziom sprawności & 0,035 & 0,011 & 3,116 & 0,0019 \\
\hline Samoocena stanu zdrowia & 0,027 & 0,011 & 2,565 & 0,0106 \\
\hline $\begin{array}{l}\text { Liczba kontaktów } \\
\text { seksualnych }\end{array}$ & 0,003 & 0,001 & 2,517 & 0,0121 \\
\hline Poziom prestiżu & 0,036 & 0,009 & 3,952 & 0,0001 \\
\hline Poziom ekstrawersji & 0,041 & 0,008 & 4,932 & 0,0000 \\
\hline Poziom sumienności & 0,019 & 0,008 & 2,475 & 0,0136 \\
\hline
\end{tabular}

* jednostkowa zmiana zmiennej objaśniającej dotyczy przeskoku o 1000 zł

Źródło: opracowanie własne.

\section{DYSKUSJA}

Uzyskane wyniki sa zgodne z innymi badaniami prowadzonymi w tym zakresie od wielu lat, nie tylko w Polsce (tu wystarczy wspomnieć chociażby największe polskie badania - Diagnozę Społeczna), ale i za granica. Wszystko za- 
leży oczywiście od tego, kogo badamy (w tym badaniu skupiono się na osobach z pokolenia X, a więc w wieku 35 lat i więcej), jak mierzmy zadowolenie z życia (czy jednym pytaniem, czy kilkoma, a jeżeli kilkoma wskaźnikami cząstkowymi, to jakimi), jakimi cechami opisujemy warunki życiowe respondentów (jakie determinanty szczęścia bierzemy pod uwagę) - czy np. pytając o stan zdrowia, posługujemy się oceną subiektywna, czy wykonujemy jakieś pomiary medyczne.

\section{Omówienie wyników}

Kwestia posiadania dzieci - w świetle innych współczesnych badań empirycznych brak potomstwa trudno uznać za istotna przesłankę poczucia nieszczęścia, czasami bezdzietność może wręcz sprzyjać dobrostanowi psychicznemu ${ }^{4}$, ponieważ kto nie ma dzieci, nie będzie narażony na przykład na stres związany z ich wychowywaniem czy na dramatyczne wydarzenia, jakie mogą spotkać rodziców (przewlekła choroba, czy nawet śmierć dziecka - jedno z najbardziej traumatycznych wydarzeń). Z drugiej strony posiadanie dziecka przynosi (szczególnie dla matek) wiele korzyści psychicznych, żeby wymienić chociażby zaspokojenie instynktu macierzyńskiego/ ojcowskiego, wzajemna bliskość i więź, doświadczanie wielkiej radości z uczestniczenia w rozwoju dziecka, zapewnienie bezpieczeństwa na starość itp. Niestety dzieci przysparzaja też problemów swoim rodzicom, zwłaszcza ekonomicznych, a to z kolei zwiększa przeważnie poziom ich depresji ${ }^{5}$ ). Mówi się więc o dwojakim oddziaływaniu dzieci na dobrostan rodziców: pośrednio negatywny (przez wzrost wydatków i pogorszenie sytuacji finansowej) oraz bezpośrednio pozytywny (zrealizowanie potrzeby macierzyństwa i inne korzyści psychologiczne).

$\mathrm{Z}$ posiadaniem dzieci wiąże się też liczba potomstwa. W podjętym badaniu okazało się, że im większa liczba dzieci, tym gorzej dla szczęścia respondentów, ale inne, prowadzone na szeroka skalę badania ${ }^{6}$ nie dają w tej kwestii jednoznaczności. Jest to więc najprawdopodobniej kwestia indywidualna: niektórzy wolą mieć więcej, inni mniej dzieci. Pewne jest natomiast to, jak wspomniano wcześniej, że zazwyczaj im więcej dzieci, tym większa bieda - dzieci generują bowiem koszty, trzeba je nakarmić, ubrać itd., a jak pokazano niżej - sytuacja materialna także jest ważnym czynnikiem decydującym o naszym zadowoleniu.

Według przeprowadzonej analizy kolejne dwie cechy, tym razem stricte ekonomiczne (bycie niezależnym finansowo oraz wartość posiadanego majątku), maja pozytywny wpływ na odczuwane szczęście. Inne badania często dowodziły, że pieniądze zapewniają szczęście, ale głównie biednym, gdyż umożliwiają im zaspokojenie podstawowych potrzeb życiowych, jednakże już po zaspokojeniu tych potrzeb dalsze zwiększanie dochodów przestaje wpływać na poziom odczuwanej satysfakcji ${ }^{7}$. Ma to też zwiazek z prawem malejącej użyteczności krańcowej, które mówi, że korzyści, jakie czerpie się z każdej

\footnotetext{
4 Tanaka, Johnson (2016).

5 Np. Werding (2014).

${ }_{6}$ Baranowska, Matysiak (2011); Kohler (2005); Margolis, Myrskyla (2011).

7 Hagerty, Veenhoven (2000).
} 
kolejnej konsumowanej jednostki dobra, są mniejsze od korzyści z poprzedniej jednostki dobra, a więc dalsza konsumpcja co prawda poprawia standard życia, ale jego poprawa z każdą jednostka dobra jest już coraz mniejsza. Jeszcze inne ważne spostrzeżenie w kwestii wpływu dochodów na szczęście jest takie, że zadowolenie z życia zależy nie od absolutnej, lecz względnej wysokości dochodu, będącej wynikiem porównań społecznych oraz porównań w czasie ${ }^{8}$. Dla naszego zadowolenie ważne jest, abyśmy byli bogatsi niż inni i bogatsi niż w przeszłości. Poza tym zaletą niezależności finansowej z perspektywy osiągania szczęścia jest to, że daje ona bardzo dużo możliwości realizacji: można spokojnie planować swoją przyszłość, bez obawy, że wszystko nagle się zawali, można czuć się bezpiecznie i mieć więcej czasu na to, co naprawdę sprawia przyjemność.

Wyniki badania pokazały też, że na poziom szczęścia ma wpływ miejsce zamieszkania, a konkretnie, że mieszkanie w dużym mieście (w Poznaniu) obniża zadowolenie z życia. Wyniki innych badań ${ }^{9}$ potwierdzają to spostrzeżenie: pod kątem psychicznym życie na wsi jest ogólnie zdrowsze od życia w dużych miastach, a tłumaczone jest to głównie czynnikami społecznymi. Podkreśla się na przykład większą rolę więzi społecznych, mniejsze osamotnienie i wyalienowanie w mniejszych, a zarazem bardziej zintegrowanych społecznościach wiejskich. Wadą dużych, anonimowych aglomeracji miejskich jest bardzo duża liczba bodźców, niezdrowy styl i tempo życia (które powoduja nadmierna stymulację i przeciążenie psychiczne), a także duża gęstość zaludnienia czy nasilenie przestępczości ${ }^{10}$.

Easterlin i in. ${ }^{11}$ udowodnili z kolei, że to, czy bardziej szczęśliwie będzie się ludziom żyło na wsi czy w mieście, zależy od poziomu rozwoju ekonomicznego kraju: w krajach lepiej rozwiniętych szczęściu sprzyja mieszkanie na wsi, w państwach biedniejszych - szczęśliwiej żyje się w miastach, a ponieważ Polska (a zwłaszcza jej regiony zachodnie) są relatywnie dobrze rozwinięte, wyniki uzyskane w badaniu Wielkopolan można uznać za logiczne - respondentom więcej zadowolenia przynosi życie w mniejszych miastach (nie w Poznaniu).

Wyniki badania pokazały też, że bardzo ważnym symptomem niskiego zadowolenia z życia jest doznanie jakiejśs wyjątkowo bolesnej porażki życiowej. Autorzy innych badań z tego zakresu podkreślaja, że takie traumatyczne porażki prowadzą do obniżenia pewności siebie, obwiniania się za doznane niepowodzenia, a te negatywne stany wyzwalaja poważne reakcje emocjonalne, takie jak depresja i niepokój ${ }^{12}$. Uzyskane spostrzeżenia o bardzo negatywnym wpływie porażek na szczęście wpisują się też w klasyczną teorię porównań Michalosa i Ingleharta, według której trzema głównymi kryteriami oceny własnego życia sa: (1) aspiracje, czyli to, czego bym chciał, (2) oczekiwania, a więc czego się spodziewałem, oraz (3) to, co uważam, że mi się należy; to, na co zasługuję. Według autorów tej teorii przekonanie, że moja sytuacja jest gorsza,

\footnotetext{
${ }^{8}$ Np. Clark, Oswald (1996).

${ }^{9}$ Np. Berry, Okulicz-Kozaryn (2011).

${ }_{10}$ Albouy (2008).

${ }^{11}$ Easterlin et al. (2011).

12 Ellenhorn (2005).
} 
niż bym tego chciał, niż tego oczekiwałem i na co zasługuję, jest źródłem wyjątkowo głębokiego poczucia nieszczęścia ${ }^{13}$.

Z kolei co do poziomu niezależności, według danych Gallup World Poll oraz badań Ingleharta ${ }^{14}$, istnieje wyraźny pozytywny związek między poczuciem wolności a szczęściem. W krajach, w których ludzie mają swobodę wyboru i kontroli swojego życia, obywatele są zazwyczaj szczęśliwsi. Nie dziwi więc fakt, że w przypadku badanych respondentów większemu szczęściu sprzyja większy poziom wolności i raczej trudno byłoby znaleźć taka grupę badawcza, której członkowie powiedzieliby, że byliby szczęśliwsi, gdyby czuli się bardziej ograniczeni. Nie ulega też wątpliwości, że oprócz wolności drugim podstawowym elementem dobrobytu jednostek jest bezpieczeństwo osobiste. Obejmuje ono nie tylko ryzyko uszczerbku fizycznego (np. napaści), ale też utraty mienia (kradzież). Badania w tym zakresie także sa jednoznaczne: im niższe wskaźniki przestępczości (większe bezpieczeństwo) tym społeczności zamieszkujące takie terytoria (kraje, prowincje, miasta) są szczęśliwsze ${ }^{15}$. Bezpieczeństwo może też dotyczyć lęku o tzw. jutro - ale w tym przypadku chodzi bardziej o omówione już wcześniej kryterium dochodowe i bycie niezależnym finansowo.

Innymi ważnymi determinantami szczęścia okazały się stan zdrowia oraz poziom sprawności. Przeprowadzone do tej pory badania dowodzą korelacji między stanem zdrowia a szczęściem na przeciętnym poziomie od 0,16 do $0,35^{16}$. Związek ten jest oczywiście najczęściej negatywny - wraz z pogłębianiem się procesu chorobowego następuje obniżanie samooceny, spadek przyjemności, wzrost przykrości, pojawiają się utrudnienia w aktywności życiowej z powodu osłabienia organizmu. Lista negatywnych konsekwencji procesów chorobowych jest więc naprawdę długa. Najciekawszym wnioskiem z takich badań jest jednak to, że subiektywna ocena własnego zdrowia (a tak badano zdrowie w niniejszym badaniu) jest lepszym wskaźnikiem wyjaśniającym dobrostan psychiczny niż ocena dokonana przez innych ludzi, a nawet profesjonalna diagnoza medyczna ${ }^{17}$ ). Człowiek czuje się lepiej, jeśli dostrzeże nawet najmniejsze oznaki poprawy, nabiera wiary w szybkie wyzdrowienie itp., z kolei oznaki pogorszenia moga go znowu łatwo wprowadzić w zły nastrój.

Z kolei wpływ obniżonej sprawności (w szczególności stanu niepełnosprawność) na poczucie zadowolenia jest dość specyficzny: różnego rodzaju schorzenia odbierają bowiem zadowolenie, ale najczęściej tylko na pewien czas. Działa tu bowiem po pierwsze mechanizm adaptacji i akomodacji. Poza tym to, co może poprawiać dobrostan osobom niepełnosprawnym, jest aktywność (szczególnie fizyczna). Jak wynika $\mathrm{z}$ badań Oswalda ${ }^{18}$, osoby chore mogą być równie szczęśliwe co zdrowe, jeżeli tylko pozostaną aktywne.

\footnotetext{
13 Michalos (2007).

14 Inglehart (2008).

${ }_{15}$ Cohen (2008).

16 Np. Okun et al. (1994).

17 Diener (2018).

18 Oswald (2008).
} 
Model regresji wskazał też na liczbę kontaktów seksualnych jako czynnik stymulujący zadowolenie z życia. Inne badania ${ }^{19}$ pokazuja, że związek między częstotliwościa kontaktów seksualnych a dobrostanem najlepiej opisuje krzywoliniowe powiązanie, w którym im większa liczba kontaktów seksualnych, tym większy dobrostan, ale w zakresie od 0 do 4 razy w miesiącu. Większa niż 4 liczba kontaktów nie powoduje już wyraźnego wzrostu zadowolenia z życia.

Czynnikiem, od którego zależy zadowolenie z życia, okazał się też prestiż, społeczny. Ogólnie uważa się, że zadowolenie rośnie liniowo wraz z prestiżem ${ }^{20}$. Jedną z oznak prestiżu jest wykonywany zawód. Wspomniani autorzy, opierając się na dużej próbie brytyjskich pracowników, stwierdzili, że zadowolenie z życia rośnie w przypadku zawodów o wyższym prestiżu. Ponadto osoby o wysokim prestiżu społecznym (czego przejawem są np. wyższe dochody i wyższe wykształcenie) zwykle zgłaszają wyższe poczucie bezpieczeństwa i są narażone na mniejsze ryzyko przestępczości, a jak już wyjaśniono - im większe bezpieczeństwo, tym większe zadowolenie z życia.

Ostatnie dwa czynniki, jakie mają znaczenie dla zadowolenia z życia respondentów, to dwie cechy związane z osobowościa: poziom ekstrawersji i sumienności. Jak piszą Furnham i Christoforou ${ }^{21}$, w ok. 52\% uczucia negatywne i pozytywne w różnych sytuacjach życiowych zależą od danej osoby (jej cech osobniczych), a jedynie w $23 \%$ - od zmieniających się sytuacji. Dzieje się tak, ponieważ ludzie zachowują pewien stały nastrój, interpretują sytuacje w charakterystyczny dla siebie sposób lub wybierają albo unikają pewnych sytuacji. Ludzie wybierają takie sytuacje, które sa zgodne z ich cechami i motywacją. Na przykład ekstrawertycy spędzaja więcej czasu w sytuacjach towarzyskich i na zajęciach fizycznych, ci zaś, którym brakuje umiejętności towarzyskich lub odczuwają wysoki niepokój wśród innych ludzi, unikają nawet wielu zwykłych sytuacji, łącznie z tymi powszechnie uważanymi za przyjemne, jak przyjęcia czy randki22.

Cechy osobowości całkiem wyraźnie determinują dobrostan psychiczny: DeNeve i Cooper dokonali przeglądu badań w tym zakresie, który pokazał, że najsilniej z dobrostanem korelują neurotyzm (przeciętnie korelacja wyniosła $-0,22)$ i sumienność $(+0,21)$, a najsłabiej otwartość na doświadczenia $(+0,11)^{23}$. Powszechnie uważa się, że ludzie szczęśliwi mają naprawdę inną osobowość od nieszczęśliwych: są bardziej otwarci, ugodowi i sumienni, mają wyższy poziom ekstrawersji, a mniejszy neurotyzmu. Z takich faktów wynika, co ludzie mogliby rozwijać w swojej osobowości, aby osiagnać (wyższe) szczęście. Niestety zarówno szczęście, jak i cechy osobowości są w dużej mierze wrodzone, a więc do końca nie wiadomo, czy uda się te cechy, jak i szczęście, stymulować.

\footnotetext{
${ }^{19}$ Cheng, Smyth (2015).

${ }^{20}$ Np. Loewenstein et al. (2015).

21 Furnham, Christoforou (2007).

22 Argyle (2004).

${ }^{23}$ DeNeve, Cooper (1998).
} 


\section{ZAKOŃCZENIE}

Ustalenie, jakie czynniki oraz w jakim kierunku i w jakim stopniu wpływają na ogólne zadowolenie z życia (taki był główny cel analizy), nie jest zadaniem łatwym, wymaga bowiem nie tylko wytypowania potencjalnych determinant szczęścia, ustalenia, w jaki sposób to szczęście będzie mierzone (jednym pytaniem czy na podstawie wskaźników cząstkowych: z zastosowaniem wag lub bez nich), ale przede wszystkim odpowiedniego zbioru danych. W niniejszej analizie posłużono się bardzo obszernym materiałem statystycznym: próba liczyła 1110 respondentów z województwa wielkopolskiego, którzy badani byli pod katem 21 subiektywnych, cząstkowych wskaźników zadowolenia z życia, zbiór zmiennych objaśniających zaś składał się z 41 czynników.

Wyniki modelowania $\mathrm{z}$ wykorzystaniem wielowymiarowej analizy regresji wskazały na 14 statystycznie istotnych determinant szczęścia, a w zestawie tych czynników znalazły się następujace cechy respondentów: posiadanie dzieci, liczba dzieci, bycie niezależnym finansowo, wartość majątku, miejsce zamieszkania, doznanie wielkiej życiowej porażki, poziom wolności/ swobody, poziom bezpieczeństwa, poziom sprawności, samoocena stanu zdrowia, liczba kontaktów seksualnych, poziom prestiżu, poziom ekstrawersji oraz poziom sumienności. Ponadto niektóre z nich na poziom zadowolenia wpływają dodatnio, niektóre ujemnie, wpływ ten ujawnia się też z różną intensywnością. Co ważne, wszystkie zauważone prawidłowości znalazły swoje potwierdzenie $\mathrm{w}$ przeprowadzonych dotychczas badaniach, aczkolwiek dotyczyły one przeważnie społeczeństw z krajów wysoko rozwiniętych (Stany Zjednoczone, Europa Zachodnia), dlatego uzyskane wnioski należy potraktować jako sygnał, że pod kątem determinant szczęścia społeczeństwo polskie (a zwłaszcza analizowane osoby w wieku 35 lat i więcej, reprezentujące tzw. pokolenie X) nie różni się zbytnio od bardziej bogatych populacji.

\section{Tomasz Szubert}

Uniwersytet Ekonomiczny w Poznaniu

tomasz.szubert@ue.poznan.pl

https://orcid.org/0000-0003-4875-8032

Albouy, D. (2008). Are big cities bad places to live? Estimating quality of life across metropolitan areas. National Bureau of Economic Research Working Paper Series 14472.

Argyle, M. (2004). The Psychology of Happiness. London: Methuen.

Baranowska, A., Matysiak, A. (2011). Does parenthood increase happiness? Evidence for Poland. Vienna Yearbook of Population Research 9: 307-325.

Berry, B., Okulicz-Kozaryn, A. (2013). An urban-rural happiness gradient. Urban Geography 32(6): 871-883.

Boarini, R. (2015). Well-being and quality of life reporting at the OECD, [w:] W. Glatzer, L. Camfield, V. Møller, M. Rojas (eds.), Global Handbook of Quality of Life. Exploration of Well-Being of Nations and Continents, Springer.

Campbell, A., Converse, P.E., Rodgers, W. (1976). The Quality of American Life: Perceptions, Evaluations, and Satisfactions. New York: Russell Sage Foundation. 
Cheng, Z., Smyth, R. (2015). Sex and happiness. Journal of Economic Behavior and Organization 112: 26-32.

Christoph, B., Noll, H.H. (2003). Subjective well-being in the European Union during the 90s. Social Indicators Research 64(3): 521-546.

Clark, A.E., Oswald, A.J. (1996). Satisfaction and comparison income. Journal of Public Economics 61(3): 359-381.

Cohen, M. (2008). The effect of crime on life satisfaction. Journal of Legal Studies 37: 325-353.

DeNeve, K.M., Cooper, H. (1998). The happy personality: a meta-analysis of 137 personality traits and subjective well-being. Psychological Bulletin 124: 197-229.

Diener, E., Oishi, S., Tay, L. (eds.) (2018). Handbook of Well-Being. Salt Lake City, UT: DEF Publishers.

Easterlin, R.A. (1995). Will raising the incomes of all increase the happiness of all? Journal of Economic Behavior and Organization 27(1): 35-47.

Ellenhorn, R. (2005). Parasuicidality and patient careerism: treatment recidivism and the dialectics of failure. American Journal of Orthopsychiatry 75: 288-303.

Furnham, A., Christoforou, I. (2007). Personality traits, emotional intelligence, and multiple happiness. North American Journal of Psychology 9: 439-462.

Hagerty, M.R., Veenhoven, R. (2003). Wealth and happiness revisited: growing wealth of nations does go with greater happiness. Social Indicators Research 64: 1-17.

Inglehart, R., Foa, R., Peterson, C., Welzel, C. (2008). Development, freedom, and rising happiness: a global perspective (1981-2007). Perspectives on Psychological Science 3(4): 264-285.

Kohler, H.P., Behrman, J.R., Skytthe, A. (2005). Partner + children = happiness? The effects of partnerships and fertility on well-being. Population and Development Review 31(3): 407-445.

Loewenstein, G., Krishnamurti, T., Kopsic, J., McDonald, D. (2015). Does increased sexual frequency enhance happiness? Journal of Economic Behavior and Organization 116: 206-218.

Margolis, R., Myrskyla, M. (2011). A Global Perspective on Happiness and Fertility. Population and Development Review 37(1): 29-56.

Michalos, A.C. (2007). Essays on the Quality of Life. Netherlands: Springer.

Okun, M.A., Stock, W.A., Haring M.J., Witter R.A. (1984). Health and subjective well-being: a meta-analysis. International Journal of Aging and Human Development 19: 111-132.

Ostasiewicz, W. (2004). Ocena i analiza jakości życia. Wrocław: Wydawnictwo Akademii Ekonomicznej im. Oskara Langego.

Oswald, A.J., Powdthavee, N. (2008). Does happiness adapt? A longitudinal study of disability with implications for economists and judges. Journal of Public Economics 88: 1359-1386.

Tanaka, K., Johnson, N.E. (2016). Childlessness and mental well-being in a global context. Journal of Family Issues 37(8): 1027-1045.

Werding, M. (2014). Children are costly, but raising them may pay: the economic approach to fertility. Demographic Research 30(Article 8): 253-276.

\section{DETERMINANTS OF HAPPINESS AMONG THE POLES OF GENERATION X}

$$
\text { Summary }
$$

The research undertaken focused on a specific group: Poles aged 35 and over, thus representing so-called Generation X. The main objective of the study was to check which factors affect overall satisfaction with life, as well as how to what extent, which was measured as a weighted average of partial satisfaction indicators from 21 different spheres of life. The weights used to establish this general indicator were the declarations of respondents on how important every sphere is in their life, how much they want to be implemented in it. To achieve this goal, the results of a survey conducted in the first half of 2017 on a sample of 1,110 respondents from the Wielkopolska Voivodeship were used, and in determining what factors significantly determine a high or low level of satisfaction a multidimensional regression analysis was used. The results of the modeling process indicated 14 out of a potential 41 determinants of happiness, and the set of these factors includes the following characteristics of respondents: having children, the 
number of children, being financially independent, the value of property, place of residence, experiencing or not experiencing great failure in life, level of freedom/ liberty, level of safety, fitness level, self-assessment of health, number of sexual contacts, social prestige, level of extraversion and level of conscientiousness. In addition, it turned out that some of these factors positively affect the level of satisfaction, some negatively, and this influence is also manifested with varying intensity.

Keywords: life satisfaction; quality of life; regression analysis; Generation X 
